The University of Akron

\title{
IdeaExchange@UAkron
}

Proceedings from the Document Academy

University of Akron Press Managed

December 2018

\section{Libraries and the Establishment of a Sámi Political Sphere}

Geir Grenersen

Department of Culture and Literature. The Arctic University of Norway. Tromsø, Norway, geir.grenersen@uit.no

Please take a moment to share how this work helps you through this survey. Your feedback will be important as we plan further development of our repository.

Follow this and additional works at: https://ideaexchange.uakron.edu/docam

\section{Recommended Citation}

Grenersen, Geir (2018) "Libraries and the Establishment of a Sámi Political Sphere," Proceedings from the Document Academy: Vol. 5 : Iss. 2 , Article 7.

DOI: https://doi.org/10.35492/docam/5/2/7

Available at: https://ideaexchange.uakron.edu/docam/vol5/iss $2 / 7$

This Conference Proceeding is brought to you for free and open access by University of Akron Press Managed at IdeaExchange@UAkron, the institutional repository of The University of Akron in Akron, Ohio, USA. It has been accepted for inclusion in Proceedings from the Document Academy by an authorized administrator of

IdeaExchange@UAkron.For more information, please contact mjon@uakron.edu, uapress@uakron.edu. 
Missionaries introduced compulsory schooling among the Sámi from the mid-18th century, some 30 years before compulsory schooling for the Norwegians. The main reason was that the missionaries wanted the Sámi to read the Bible in their own language - "the language of the heart," as was often said. From the 19th century Sámi pupils were included in the Norwegian schooling system, and the missionary schools were closed. From 1850, teaching in Sámi was gradually terminated, and education for Sámi pupils was mainly in Norwegian. Although you could find geographical variations, the Sámi population had high reading proficiency from the early 19th century onwards.

No research has been done on the relationship between the reading proficiency and political mobilization among the Sámi. I have done a preliminary study of the book loans of two Sámi political pioneers at the library of Troms $\varnothing$ Teaching College, in the period 1896 to 1898. Anders Larsen and Isak Persen borrowed 167 books during their two years at the college. I have categorized these books according to title, genre and date. A clear majority of the books were either novels from the modern breakthrough in Scandinavian literature, or historical works, social critique, science and ethnography. From this I suggest that the Sámi political resistance that started in the early 20th century was probably connected to the spreading of new, revolutionary ideas through the Norwegian library system.

\section{Who Are the Sámi?}

The Sámi is the indigenous population of the middle and Northern part of Scandinavia. Their territories are part of four countries: Norway, Sweden, Finland and Russia. Traditionally the Sámi have lived by nomadic reindeer herding, farming, fishing and hunting. Up to the 18th century they were organized in small, decentralized units (called "Siidas" in Sámi) regulated by unwritten agreements very different from the centralized and hierarchical political structure in Scandinavian countries (Manker \& Vorren, 1962). New archeological research and new historical perspectives show that they were integrated into a larger Scandinavian and European economy before and during the Viking period. The Sámi traded valuable fur and skin products with the Vikings, and later to European nobility, and Sámi living along the coast built ships and vessels for sale (Hansen \& Olsen, 2004). This reciprocal, economic relationship between the Sámi and their neighboring population declined when the Danish-Norwegian state expanded into Sámi areas around the beginning of the 18th century.

\section{The Danish-Norwegian Mission}

From 1720 onwards, the Danish-Norwegian state intensified mission towards the Sámi. The Protestant mission wanted to make sure that the Sámi learned the 
Christian faith by heart. To accomplish this, they translated the Bible and religious texts into Sámi, and established schools to teach Sámi children to read. Sámi children in many areas of Northern-Norway learned to read 30-40 years before the introduction of compulsory schooling in Norway.

The Protestant missionaries systematically tried to destroy the old pagan religion, and its sacred view of the landscape, including the use of sacrificial sites (Hansen, 1997, p. 131). A central goal of this policy was to forbid specific Sámi rituals and destroy Sámi material culture, especially the noide (noide, Sámi name for shaman) drum, used by the shaman in his/her travels to "the other world" (Hansen \& Olsen, 2004). Today, only a handful Sámi shaman drums are preserved, mostly in central European museums. The traditional Sámi chanting, the "joik" was also forbidden; even today, to "joik" in churches is considered unchristian. The Sámi turned to Christianity, but they brought parts of their own religion with them, practices that look like Christian practices but originate in their old pagan religion.

Through the religious revival in the mid 19th century, the laestadianism, the Sámi population in large parts of Norway got a common, spiritual basis that kept their culture from breaking apart during the harsh Norwegianization period that was to follow. The laestadianism got its name from the priest Lars Levi Laestadius. His mother was Sámi and he was educated at the University of Uppsala. Laestadius spoke and preached in the Sámi language, he placed Sámi values above Norwegian values, allowed ordinary Sámi as lay preachers, and emphasized that every person should take "the word" - God's word - to his/her heart through their own reading of the Bible. And there was an obligation to "spread the word," to preach the Laestadian version of Christianity to other people in Northern Scandinavia. Reading and writing were important aspects in practicing laestadianism, and there was a strong influence from pietism in this religious awakening.

\section{Norwegianization}

From 1850 onward, the Norwegian authorities decided to restrict the use of Sámi languages in schools. Inspired by nationalism, and fear of Russian and Finnish expansionism, the authorities decided that from now on Norwegian should be the main language in schools (Eriksen \& Niemi, 1981). The Sámi should be educated into "good Norwegians," believing that if they learned Norwegian language from first grade, they would feel like Norwegians when compulsory school was over. To ensure this, a document called "the Instruction" was launched that set up in detail how this should be carried out in the classrooms (Kjerschow, Killengreen \& Smitt, 1880). The instruction was to be posted on every classroom wall. Norwegian should be the only language in use in every situation both in the classroom and in the schoolyard. Exceptions could be made only if the child's mental health was at risk by not being allowed to talk their mother tongue. Sámi language could only be used 
to help out when the child or children did not understand Norwegian. Most Sámi children did not speak or understand a word of Norwegian when they started school.

Although the instruction from the school department was not fully enforced, the consequence was that thousands of children with Sámi as their mother tongue never got the chance to use their language at school between 1850 and 1962 . In 1962, the instruction was formally abandoned by the Norwegian Parliament and the policy of assimilation was reversed into what today is a policy that constitutionally accepts the Sámi as one of two official peoples of the Norwegian state. The assimilation policy continued de facto into the 1970s, and only with the dramatic Alta-Kautokeino uproar in 1979, over the damming of a large river that ran through the Sámi homeland, was a new policy started. It has led, among other effects, to the establishment of a Sámi Parliament, a Sámi University College and new laws in the Norwegian constitution that guarantee the Sámi the right to develop their language and culture.

During the last 50-100 years a small percentage of the Sámi have kept up the traditional livelihood in reindeer husbandry, farming, hunting or fisheries. The rest have largely been absorbed in the same occupational patterns as the majority population (Stordahl, 1996). There is no overall registration of the Sámi population based on ethnic criteria. No one knows exactly how many Sámi there are today, but it is estimated to be at least 50,000 Sámi in Norway, and in total about 80-100,000 in Scandinavia (including Norway) and Russia. About 12,000 of the Sámi in Norway speak Sámi as their first language, and around 3,500 still have reindeer herding as their main occupation (Statistics Norway, 2010). The Sámi today have the same level of income and living conditions as the majority population, and Sámi women have a higher educational level than Norwegian and Sámi men.

\section{Religious Books and Readings}

Between 1720 and the 1870s, thousands of religious books were distributed among the Sámi. They were printed in Sámi languages, or with double text: Sámi on one page, Norwegian on the parallel page. This helped raise the level of literacy among the Sámi and the lay population in general. For 150 years only religious books, and some school books, were distributed to the Sámi population (Tvete, 1955). But from the mid 19th century onward, in an effort to make the Norwegianization policy more efficient, the state demanded that religious books and school books should be printed with only Norwegian text. The authorities had denied Sámi pupils to talk Sámi at schools, now they were not allowed to read Sámi either. The Church was divided on this question, and many priests were openly against it and continued to use Sámi books in their services. Some teachers also continued to use Sámi books, and talk Sámi in the classrooms. Many of the Sámi religious books that had been printed throughout the 18th and 19th century continued to be used, and some civil 
religious institutions also continued to print books in Sámi. Many Sámi continued to read their beloved books in the "language of the heart," their native language.

\section{The Growth of Libraries in Sámi Areas}

Fewer Sámi religious books were printed in the Sámi language towards the end of the 19th century. At the same time, the Norwegian library system was extended and public libraries were established throughout the country, including the Sámi areas. Increased public funding made way for better library facilities, larger collections and longer opening hours. Some private libraries were also established during this time, the most known was Finmarksbibliotheket ("the Finnmark Library"), established in 1895 by teachers and merchants in the city of Vadsø. The library built up an impressive collection of books, paintings, photographs and prints about Finnmark. Unfortunately, most of the records from this library are lost.

The library at Troms $\varnothing$ Teaching College was also of great importance. The college was established in 1827 and was the only higher educational institution in Northern Norway in the 19th century. It was established with the aim of educating teachers to the Sámi areas of Northern Norway. Around 1900 this library had a comprehensive collection of modern literature, science, ethnography and pedagogy. Part of the book collection is still intact, stored in the basement of today's University library in Troms $\emptyset$. All lending protocols and book-lists are preserved. This is the only comprehensive library archive in Norwegian archives from this period that can shed a light on Sámi use of libraries. The reason for this is twofold: Norwegian archives have traditionally not labelled documents in Sámi or from Sámi areas qua Sámi documents, therefore to search for specific Sámi traits in an archive can be an exhausting experience (Maliniemi, 2009, 2010). The other reason is the total burning of the county of Finnmark in 1944 by the German army, where most of the local and regional archives were lost.

As a consequence of the expansion of public libraries, most of the municipalities in Northern Norway had a library around 1900 (Fisher et al., 1901). Through the libraries, the Sámi public increasingly got access to books and periodicals, and could be informed on politics, culture, science, literature and economics. The school directors and the leaders of the school and Church departments in the government, saw the libraries as agents of Norwegianization. The intention was to motivate the Sámi to prefer to read Norwegian, and that in this process they would realize that Norwegian identity was the preferable one. After a four-month travel inspection through Finnmark in 1887, school director Killengreen, one of the main strategists behind the Norwegianization policy, reported on the Sámi- and Kvens (the Finnish population) use of libraries in every school district he visited. According to Killengreen, in some Sámi districts, 
"Lappish youth seek Norwegian reading quite often"1 (Killengreen, 1887). One of these municipalities was Nesseby, a place with 1,500 people at the end of 19th century, most of them Sámi. A boy called Isak Persen grew up in Nesseby, in a trilingual milieu where Sámi, Finnish and Norwegian were spoken. He was 12 years old in 1887 , and probably one of the young Sámi who went to the local library to read and be informed.

\section{The Library at Tromsø Teaching College and its Importance for Sámi Students}

Nine years later, in 1896, Persen was admitted to the Troms $\varnothing$ Teaching College. Persen (he had then changed his name to Saba) was ten years later to be the first Sámi elected to the Norwegian Parliament. In 1897, another young Sámi, Anders Larsen, was admitted to the College. In 1903 Larsen started and edited the first Sámi newspaper, Sagai Muittalaggje ("The News Reporter"), and he later wrote and published the first Sámi novel, Baivve-Alggo ("Dawn") in 1912. The two students soon became best friends and found that they had common interests in the struggle for a fairer treatment of the Sámi people in Norway. The Sámi public had to be informed about the rights of the Sámi people as "the oldest inhabitants in Norway" (Zachariassen, 2012). There was a need for political action, a public sphere where Sámi political questions were discussed had to be established. Persen and Larsen's years at Troms $\emptyset$ Teaching College has been emphasized as a period were their mutual political project was developed (Jernsletten, 1986; Zachariassen, 2012a, 2012b). They participated in the political and literary clubs at the college where Norway's struggle for independence from Sweden were intensely debated. Larsen and Persen were inspired by the idea of Norwegian national independence and transferred these ideas to a form of Sámi nationalism (Jernsletten, 1986, p. 49). In the years to follow they published articles, pamphlets and books emphasizing the proud history of the Sámi people. We can assume that these ideas also were nurtured through their access to the college library, which contained most of the relevant fiction by Norwegian writers after the "modern turn" in the 1870s, like Ibsen, Bjørnson, Lie, Garborg, Boyer and Hamsun. The library contained history books by leading Scandinavian historians, covering old Norse history and mythology, the Roman Empire and modern European history. They had central works of ethnographers and linguists that covered Sámi history, mythology, community life, language, natural history, natural sciences, pedagogy and didactics and periodicals on many of these subjects. Most of the books were in Norwegian, a few in Finnish, and religious and linguistic books in the Sámi language (Tilvekstprotokoll Bibliotek, 1881).

\footnotetext{
1 "Lapp" and "Lappish" is today a derogatory word for the Sámi, but it was used up to the 1950s.
} 
The most important sources have been the library catalogues and lending registers from the Troms $\varnothing$ College of Education. All these protocols, from the start of the college in 1827 and up to today, are to be found at the National Archive of Norway. Larsen and Persen started to borrow books from the first week they attended the College. Normally two books a week, but sometimes three or four. During their two years at Troms $\varnothing$ Teaching College, Larsen and Persen borrowed 167 books altogether: Persen borrowed 100, and Larsen borrowed 67. Their loans can be put into four categories:

$\begin{array}{ll}\text { Fiction/plays } & 56 \text { books } \\ \text { Historical works/Social critique } & 41 \text { books } \\ \text { Science/Ethnography/Travelogue } & 33 \text { books } \\ \text { Religion/Mythology/Misc. } & 37 \text { books }\end{array}$

One might believe that what Larsen and Persen read in the library at Troms $\varnothing$ Teaching College should be primarily religious books - the kind of books they were accustomed to through the compulsory school and in their homes (Tvete, 1955). But not so, under the category "religion, mythology, miscellaneous" in Persen's loans, we find only 6 books of strictly religious character, and 7 of Larsen's loans are in this category. Of these 13 books a few are scriptures or interpretations of the scriptures, like the Bible in Danish translation, G. Kautsch Die Heilige Schrift der Alten Testaments, Luthers Catechism in Norwegian translation and Müller Profetiske og poetiske skrifter ("Prophetic and Poetic Writings") from the Old Testament, all borrowed by Persen. Larsen borrowed only religious books with a philosophical angle, where faith and the Christian belief systems are discussed, like Det hellige liv ("The Holy Life"), written by G. Fasting, a liberal theologist compared with Søren Kirkegaard. They also read ethnographic studies, most of them by the Norwegian linguist and ethnographer J. A. Friis, a linguist who made the first comprehensive dictionary over the Sámi language.

Nearly one-third of what Larsen and Persen read were novels that belong to what is called the Modern Breakthrough in Scandinavian literature. This is the scholarly term on the strong movement of naturalism and debating literature in Scandinavia and Europe, which replaced romanticism near the end of the 19th century (Fulsås \& Rem, 2017). The authors of the Modern Breakthrough adopted liberal views on themes like religion and sexuality and expressed a strong motivation to a more scientific world-view. Female writers also gained influence during this time. Larsen and Persen read novels and plays by the leading authors in the Modern Breakthrough, like Bjørnstjerne Bjørnson, Jonas Lie and Henrik Ibsen. They read works that cover the French revolution and the development in Europe during the decades after the French revolution, like O. V. Leixners Unsere Jahrhundert, Volume 1, 1789-1830 (in Norwegian translation). Some of the history 
books, like A. Ræder Historien i Fortcellinger ("History through Narratives") they borrowed for longer periods. Persen also borrowed the Finnish national epos Kalevala in his first semester at the school; he read it in Finnish, its original language. His reading of Kalavala points forward to his later work with Sámi folklore: as a student he assisted professor Just Qvigstad, who also was the head of Troms $\varnothing$ College, on the collecting of Sámi fairy tales and place names. Qvigstad was a renown Sámi linguist and ethnographer. In Qvigstad's comprehensive work on Sámi fairytales, Larsen collected around 100 of the stories (Qvigstad 19271929). In 1905 Persen writes: "Every people that will avoid to be swallowed by another people must take care of its folksongs, fairytales and legends based on the foremothers and -fathers' language and customs" (Jensen, 2009, my translation).

There is good reason to believe that the books and periodicals Larsen and Persen read at Troms $\varnothing$ College Library had a strong influence on their later careers and political views. It is, however, necessary to do more research on the connection between the relatively high reading proficiency among the Sámi, an expanding library system and the revolutionary thoughts that developed among the Sámi political elite in the early 20th century.

\section{References}

Eriksen, K. E., \& Niemi, E. (1981). Den finske fare. Oslo: Universitetsforlaget.

Fet, J. (2003). Skrivande bønder: Skriftkultur på Nord-Vestlandet 1600-1850. Oslo: Samlaget.

Grenersen, G. (2015a). Finnefondet: Et fornorskningsinstrument eller et ekstra lønnstillegg?-En gjennomgang av fondets midler til lærerne 1901-1902. Historisk tidsskrift, 4, 609-633.

Grenersen, Geir (2015b). The role of the libraries in the Norwegianization Policy 1880-1905. Proceedings from the Document Academy, 2(1), Article 11. Retrieved from https://ideaexchange.uakron.edu/docam/vol2/iss1/11

Fisher, K., Heiberg, J. V., \& Nyhus, H. (1901). Folkebogsamlinger $i$ Norge. Kirkedepartementet: Kristiania.

Fulsås, N., \& Rem, T. (2017). Ibsen, Scandinavia and the making of a world drama. Cambridge, UK: Cambridge University Press.

Hansen, L. I., \& Olsen, B. (2004). Samenes historie: Fram til 1750. Oslo: Cappelen akademisk forlag.

Hansen, L. I. (1995). Saami society through time. American Anthropologist, 97(1), 131-133.

Manker, E., \& Vorren, Ø. (1962). Lapp life and customs: A survey. London: Oxford University Press.

Jensen, L. A. (2009). Isak Saba. Norsk biografisk leksikon. Retrieved from https://nbl.snl.no/Isak_Saba 
Jernsletten, R. (1986). Samebevegelsen i Norge: ide og strategi 1900-1940. University of Tromsø: Hovedoppgave i historie.

Kjerschow, C., Killengreen, J., \& Smitt J. (1880). Instrux for Laererne i de samiske og kvanske Overgangsdistrikter i Troms Stift. Troms $\varnothing$ : Stiftsdirektion.

Killengreen, J. (1887). Indberetning om en Inspektionsreise til Finmarkenforetaget $i$ Tiden fra 2den Februar til 7de Juni 1886. Kristiania: Kirkedepartementet.

Maliniemi, K. (2010). Arkivdokumentene forteller. To kommuner-to typer minoritetspolitikk. Oslo: ABM-Utvikling.

Maliniemi, K. (2009). Public records and minorities: Problems and possibilities for Sámi and Kven. Archival Science, 9(1), 15-21

Statistics Norway (2010). Sámi statistics 2010. Retrieved from www.ssb.no/emner/00/00/20/nos_samer/nos_d437/tab/50.htm

Stordahl, V. (1996). Same i den moderne verden : endring og kontinuitet $i$ et samisk lokalsamfunn. Karasjok: Davvi Girji.

Tilvekstprotokoll Bibliotek. (1881). Seminarsamlingen, Boks 304. Tromsø: The National Archives of Norway.

Tvete, B. (1955). Skolebøker for samebarn i Norge fra Thomas von Westen til $i$ dag. Oslo: Oslo University.

Qvigstad, J. (1927-1929). Lappiske eventyr og sagn Oslo: Aschehoug.

Udlånsprotokol for Troms $\emptyset$ Seminar-bogsamling. (1881). Seminarsamlingen, Boks 304. Troms $\varnothing$ : The National Archives of Norway.

Zachariassen, K. (2012a). Samiske nasjonale strategar. Karasjok: Č́lliidLágáus.

Zachariassen, K. (2012b). Isak Saba, Anders Larsen og Mattio Aikio-ein komparasjon av dei samiske skjønnlitterære pionerane i Norge. Nordlit, 29, $1-13$. 